of the Director, Library Learning Center, Kentucky Wesleyan College, 3000 Frederica, Owens boro, KY 42301

- The Directory of Unique Museums, edited by Bill Truesdell (166 pages, 1985), describes over 300 highly specialized museums located throughout the United States and Canada. Arranged alphabetically within each state and province, listings provide street address, zip code, telephone number, and hours of operation. Copies are available for $\$ 24.95$ from Oryx Press, 2214 North Central at Encanto, Phoenix, AZ 85004-1483. ISBN 0-89774197-8.

- The Information Economy in the U.S.: Its Effect on Libraries and Library Networks (59 pages, 1985), the proceedings of the Library of Congress Network Advisory Committee Meeting, November 14-16, 1984, have been published as Network Planning Paper no. 10 by the Library of Congress. The aim of the meeting was to provide attendees with a working definition of the information economy and explain how libraries fit into and are affected by it. Copies are available for $\$ 7.50$ from the Customer Services Section, Cataloging Distribution Service, Library of Congress, Washington, DC 20541. ISBN 0-8444-0502-7.

- Library and Information Services in a Learning Society (93 pages, 1985) is the 13th annual report of the National Commission on Library and Information Science, which advises the Executive and Legislative Branches on national library and information-related policies. In 1983-84 NCLIS issued a statement in response to A Nation at Risk and investigated fee-supported services in public and academic libraries. A summary of the Commission's goals for establishing a national program for library and information services, and a list of its projects and publications are included in the appendices. Copies are $\$ 5$ (prepaid) and may be ordered from Dept. 36-NJ, Superintendent of Documents, Washington, DC 20402. Stock number 052-003-00991-9.

- Organizing for Preservation in ARL Libraries, SPEC Kit \#116 (131 pages, July 1985), details the results of an Office of Management Studies survey of 27 research libraries identified as having a preservation department or planning one. The kit includes initial planning statements, rationales for program placement, organization charts, and job descriptions. SPEC kits are available by subscription from the SPEC Center, ARL/OMS, 1527 New Hampshire Ave., N.W., Washington, DC 20036. Individual kits are available for $\$ 20$ each, prepayment required.

- A Survey of Manuscript Sources for the History of Psychiatry and Related Areas in the Rockefeller Archive Center, compiled by James E. Shelley (107 pages, June 1985), lists the Center's holdings for the years 1910-1974. A copy may be requested from the Rockefeller Archive Center, Pocantico Hills, North Tarrytown, NY 10591-1598.

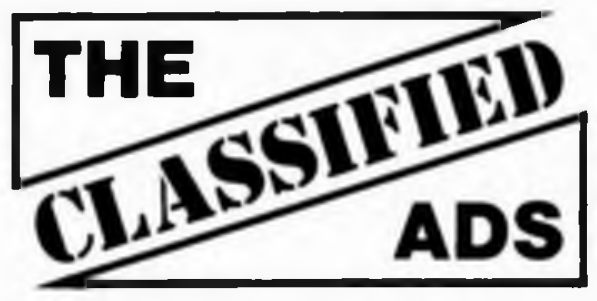

Deadllnes: Orders for regular classified advertisements must reach the ACRL office on or before the second of the month preced ing publication of the issue (e.g. September 2 for the October issue) Late job listings will be accepted on a space-available basis after the second of the month.

Rates: Classified advertisements are $\$ 5.00$ per line for ACRL members, $\$ 625$ for others. Late job notices are $\$ 12.00$ per line for members, $\$ 14.00$ for others. Organizations submitting ads will be charged according to their membership status.

Telephone: All Ielephone orders should be confirmed by a wrt ten order mailed to ACRL headquarters as soon as possible. Orders shoulc be accompanied by a typewritten copy of the ad to be used in proofreading. An additional $\$ 10$ will be charged for ads taken over the phone (except late job notices or display ads).

Guidelines: For ads which list an application deadline, that date must be no sooner than the 20 th day of the month in which the notice appears (e.g. October 20 for the October issue). All job announcements should include a salary figure Job announcements will be edited to exclude discriminatory references. Applicants should be aware that the terms faculty rank and status vary in meaning among institutions

JOBLINE! Call (312) 944-6795 for late-breaking job ads for academic and research library positions. A pre-recorded summary of positions listed with the service is revised weekly; each Friday a new tape includes ail ads received by 1:00 p.m the previous day. Each listing submitted will be carried on the recording for two weeks. The charge for each two-week listing is $\$ 30$ for ACRL members and $\$ 35$ for non-members.

Fast Job Listing Service: A special newsletter for those actively seeking positions. This service lists job postings received at ACR headquarters tour weeks be'ore they appear in C\&RL News, as we as ads which because of narrow deadlines, will not appear in C\&RL News. The cost of a six-month subscription is $\$ 10$ for ACRL mem bers and $\$ 15$ for non-members.

Contact: Classified Advertising Dep't, ACRL, American Library Association, 50 E Huron St, Chicago, II 60611: (312) 944-6780.

\section{POSITIONS OPEN}

ACOUISITIONS LIBRARIAN, Harold R. Yeary Library (search ex tended). Responsible for ordering and receiving library materiais managing materials. budget, payment process, and fund account ing reporls; maintaining records for bibliographic control Supervises and trains 6 FTE support slaff and coordinates technical ser vices with the catalog librarian. Reports to the library director and parlicipates in planning and formulation of policies and budget recommendations. Requires MLS from ALA accredited library school and minimum of 2 years acquisition experience. Must have leader ship ability, good interpersonal skills, and be able to communicate complex verbal and written instruction. Academic library experience, knowledge of automated systems, and tacility in Spanish desirable. 12-month contract. Good slate benefits. Salary $\$ 20,000-\$ 28,000$ depending on qualifications. Bilingual-bicultural border community. Deadline: November 1 or until filled. Applicants should send resume, and names of 3 references to: Screening Com. mittee. Harold F. Yeary Library, Laredo State University. West End Washington St., Laredo, TX 78040; (512) 722-8001, x40C

AGRICULTURAL LIBRAFIAN AND SELECTOR FOR AGRICULTURAL SCIENCES. Setting: currently under construction, the University of Florida's Central Science Library will conlain 440.000 vol umes and 650,000 microforms in the areas of agriculture, the life and physical sciences, and mathematics. Responsibilities: plan, develop, manage and evaluate all services to off-campus units of the Institute of Food and Agricultural Sciences (the university's statewide agricultural research and education organization); provide general supervision of the science library's interlibrary loan services; man age and develop the collection in designated areas of agricultural 
sciences; serve as one of the reference librarians for agriculture and assist with general science reference. Requirements: ALA accredited MLS; knowledge of collection development arinciples and research methodologies; at least 5 years' professional experience; supervisory, interpersonal and communication skills. Preferred qualifications: an academic background in ag ricultural or biolog. ical sciences; experience in collection development; two vears professional experience in agricultural reference services. Benefits 12 month, tenure track appointment with faculty status; 22 days vacation, TIAA/CREF or other retirement options, no state or iocal personal income tax. Salary ranges: Associate University Librarian, $\$ 17,710-\$ 31,900$; University Librarian, $\$ 21,110-\$ 38,000$. Send letter of application and resume with names, addresses and phone numbers of 3 professional references by November 4 to: Lynn Badger, Library Personnel Officer, 236 Library West, University of Florida, Gainesville, FL 32611. An AA/EO employer.

ARCHIVES LIBRARIAN. Under the direction of the Head of Manuscripts. Archives and Special Collections, supervises the operations of the archives program within the unit. Responsibilities include analyzing and maintaining the collection; selecting, training and supervising support staff; appraising, processing, arranging and cataloging collections; applying computer-based techniques to the contro of and access to collections; reference; preparing exhibits; writing grant proposals; physical maintenance and preservation of the collections. The incumbent will be expected to liase with campus offices

\section{STANFORD UNIVERSITY LIBRARIES}

The Conservation Officer plans, implements and manages the Conservation Program in support of the Collection Development and Management Program at the Stanford University Libraries.

The Conservation Officer is responsible for supervision of staff, managing and conducting patron awareness and staff development programs, budget preparation and management, coordinates processes with the Collection Development Officer, prepares promotional materials and exhibits, works with the Library Development Officer to obtain supplemental funding, represents Stanford on the RLG Preservation Committee. Responsible for coordinating conservation emergency preparedness program and for providing consultation and assistance to the university community in conservation emergencies

An MLS or the equivalent in training and experience, several years of conservation experience or training, demonstrated ability to manage and lead a dynamic program in a rapidly changing and complex research library environment, effective communication and interpersonal skills required.

Appointment will be made at the Associate $\mathrm{Li}$ brarian $(\$ 26,000-\$ 33,500)$ or Librarian $(\$ 20,000-\$ 41,500)$ rank depending on experience. Apply before December 13, 1985. Refer to vacancy $\# 277 / C R L$. Send complete cover letter and resume, with the names of three references to:

\section{Carolyn J. Henderson \\ Library Personnel Officer \\ Stanford University Libraries Stanford, CA 94305}

regarding university records and assist in developing the archival program in concert with approprate university officers and person nel. Tenure-track position. Required: ALA-accredited MLS manuscripts/archival experience, preferably with institutional rec ords; communication skills. Preferred: supervisory experience; fa miliarity with computer applications to manuscripts/archival process ing; training in archival management and historical research methods; master's degree in the social sciences or humanities; and knowledge of records management. Rank: Librarian II. Salary: commensurate with qualifications and experience, minimum $\$ 17,500$. TIAA/CREF. Broad insurance program, 22 days vacation and 12 days sick leave per year. Send letter of application, resume, and names and addresses of three references to: Donna L. McCool. Assistant Director for Administrative Services. Washington State University Libraries, Pullman, WA 99164-5610. Application review begins November 15, 1985. Washington State University is an equal opportunity, affirmative action employer.

ASSISTANT DOCUMENTS LIBRARIAN. Montana State University Libraries, Bozeman, Montana. A fiscal-year, tenure track faculty position, available as soon as possible. Responsibilities: assist documents librarian with all aspects of work in the documents depart.

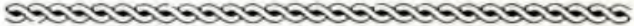

\section{LIBRARY DIRECTOR}

\section{University of North Carolina at Chapel Hill \\ Health Sciences Library}

The University of North Carolina at Chapel Hill invites applications and nominations for Director of the Health Sciences Library. The position is a major post, leading a library with a full-time equivalent staff of 61 , an active program of services, a budget of over \$2 million, a collection of over 220,000 volumes, and a 6-story building completed in 1982. The library serves 7,000 students and faculty in 5 professional schools (Dentistry, Medicine, Nursing, Pharmacy, and Public Health), North Carolina Memorial Hospital, and several research centers and institutes

The Director reports to the Vice-Chancellor for Health Affairs and serves as a peer of the deans of the professional schools. Required: demonstrated strong administrative experience in program development, personnel management, and fiscal planning, as well as leadership ability, active service to the profession, ability to work effectively with staff and the university community, and a sense of vision. ALA-accredited master's necessary. Salary in excess of $\$ 50,000$ and negotiable. Position available on or about July 1, 1986.

Send letter of application, currioulum vitae, and names of 3-5 references to:

\section{H. Robert Brashear, Jr., M.D. Chair, Search Committee Division of Orthopedic Surgery 250 Burnett-Womack Building 229H University of North Carolina at Chapel Hill Chapel Hill, NC 27514}

Deadline for applications November 1, 1985.

An affirmative action, equal opportunity employer. Women and minorities are encouraged to apply

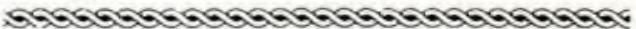


ence from ind viduals familiar with your professional qualifications by October 15, 1985 lo Edward S. Warfield, Johns Hopkins Universily, Office of Personnel Services, Foom 146, Garland Hall, Baltimore, MD 21218. Affirmative action equal opportunity employer

BIBLIOGRAPHIC INSTRUCTOR FOR SCIENCE/TECHNOLOGY, the University of Toledo. Duties: Responsible for eslablishing a bibliographic instruction program for the sciences; work at Information/Reference Desk; collection development; database searching. This position is within the bibliographic instruction department. Qualifications: MLS from an ALA-accredited school, undergraduate degree in science acceplable but advanced coursework preferred, library experience required; teaching experience desirable. Salary is $\$ 22,000$ depending on experience and qualifications. Faculty status, tenure-track, twelve-month contract. Position available April I, 1986. Completed ietter of application, resume, and names of at least three references must be recelved by November 1, 1985. Contact: Angelo Waliace, Chairperson, Search Committee, Carison Library, The University of Toledo, $2801 \mathrm{~W}$. Bancroll Street, Toledo, OH 43606. An equal opportunity/affirmative action employer.

BUSINESS AND ENGINEERING REFERENCE LIBRARIAN. Dartmouth College Library is seeking a reference librarian for the Feldberg Business and Engineering Library which serves the Amos Tuck School of Business and the Thayer School of Engineering at Dartmouth College. The person we are seeking will be capable of working as a member of a reterence services leam in an innovalive and technologically sophisticaled library utilizing Ihe Dartmouth Online Catalog, RLIN, OCLC, online database vendors such as Dow/ Jones. Nexis, BRS, and DIALOG; as well as microcomputers. Responsibilities include the provision of reference services including bibliographic instruction and online searching. consullation wilh faculty to delermine instructional and research interests, and collection development of the reference collection. Qualifications: ALAMLS. educational background graduate degree preferred, in busıness, economics, or engineering; and a minimum of 2 years post-MLS experience in an academic or special library are required. Experience in on line database searching and library applicalions of microcomputers is highly desirable. Salary and rank commensurate with experience and qualifications with a minimum of $\$ 17,500$ for Librarian I or $\$ 20,000$ for Librarian II. The search committee will begin reviewing resumes Oclober 28, 1985. Send resume to Phyllis E. Jaynes. Director of User Services, 115 Baker Library. DarImoulh College. Hanover, NH03755. Darlmouth College is an AAIEEO/M/F employer and

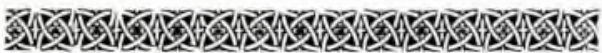

\section{ASSISTANT ART LIBRARIAN}

The Assistant Art Librarian assists the Head, Ar and Architecture Library in reference and basic collection development activities, including bibliographic instruction and some book selection. Supervises staff in absence of Head Librarian. Reading knowledge of two foreign languages (preferably French, German, Italian, or Spanish), effective communication skills, ability to work under pressure with a variety of people, and MLS or demonstrated equivalent, plus BA in art history are required. Reference and collection management ex. perience in art or architecture, and experience with automated reference sources are desired.

Assistant/Associate Librarian

rank, $\$ 23,500-\$ 33,500$ per annum based on qualifica tions and experience. Apply by November 15, 1985 to Carolyn J. Henderson, Stanford University Libraries, Stanford, CA 94305. Cite \#270/CRL on all correspondence.

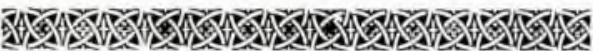

minority candidates are encouraged to apply.

BUSINESS REFERENCE LIBRARIAN, the University of Nevada Reno, a Land Grant University. Participates actively in general refer. ence desk services with emphasis on business reference services serves as liaison to Collece of Business Administration; participates in instructional services program including some formal teaching. some computer searching especially for reference purposes. MLS or equivalent 5 th year degree from ALA-accredited program. Undergraduate or graduate degree in business desirable Appropriate experience in academ c or research library reference service including knowledge of business reference sources. Strong communications and interpersonal skills. Faculty status requires that librarians meet faculty standards for appointment. promotion and tenure. Salary minimum of $\$ 22.000$, depending upon qualitications and experience. 12-month appointment. TIAA/CREF. 24 days vacation. Open January 1, 1986. Mountains, desert, lakes. 5 hours by car from San Francisco. Send resume and names and adcresses of three references to: Ruth H. Donovan, Associate Director, University of Ne vada Reno Library, Reno, NV 89557, by October 31, 1985. An AA/EO employer.

CATALOG LIBRARIAN. Responsibilities include cataloging (some orıginal) and classification of monographs, serials, and various media. Some supervision required Reports to Head of Technical Ser vices. Some evening/weekend work should be expected. Qualifica tions include ALAMLS, experience with OCLC or other utility, LC Classification, AACR2, US Docs, willingness to work well with all lev. els of slaft Minimum salary $\$ 18,000$. Immediate opening. Position is faculty-rank, lenure-track, 12-month, full-time with good fringe bene fits. Send resume and names of three references (with titles, ad dresses, and phone numbers) who have observed work relation ships and professional abilities to: Library Search Committee, c/o Kathy Essary, Chair, University of Arkansas at Little Rock, 33rd and University, Little Rock, AR 72204. The University of Arkansas at Little Rock is an affirmative action, equal opportunily employer and actively seeks the employment of minorities and women.

CATALOG LIBRARIAN. Responsibilities include original and OCLC cataloging and classification of monographs, serials and nonprint materials; catalog mainlenance and authority work; converting records into machine-readable form; special projects; and assisting in the general operation of the catalog department. Reports to the Head ol Cataloging. MLS from ALA-accredited school. Must be able to use AACR2, LC classification and subject headings and OCLC. Faculty rank and status with fringe benefits. Salary: $\$ 18,000$. Fosition available December 1, 1985. Submit resume with names of three references by October 31, 1985, to Perry Bratcher, Chair of Search Committee. W. Frank Steely Library, Northern Kentucky University High and Heights, KY 41076. Northern Kentucky University is an af lirmative action, equal opportunity employer and actively seeks the candidacy of minorities and women

CATALOGER. Assistant Librarian (Anticipated) 10 participate in adding the holdings of Norlh American libraries to the international Eighteenth-Century Short Tille Catalogue database. Qualifications: MLS; advanced degree in History or English with relevant specialization desirable; computer cataloging experience desirable. Available November 1, 1985. Three year term position. Salary: $\$ 16,500-\$ 18.000$. depending upon qualifications. Preference will be given to applications received by November 1, 1985. Write to: Judith C. Singlelon, College of Arts \& Sciences, Louisiana State Universily, Baton Fouge, LA 70803-5111. LSU is an equal opportunity employer

CATALOGER. For retrospective conversion project. Search reopened. Position funded for 12 months. Will consider applications from catalogers who are able to work a minimum of 6 months. To work with complex monographic manual records deferred during previous conversion project and to convert records to machine read. able form using OCLC. Duties may include original cataloging, verificalion of member input records, supervision of one clerk. Person will work independently within already established policies and procedures: reports to Head of Catalog Section. ALA-accredited MLS minimum five years post-MLS monographic cataloging experience: knowledge of AACR2 and previous cataloging rules and praclices. LC classilication, LCSH: familiarity with OCLC or other bibliographic ullility. Salary $\$ 2,100 /$ month: no benefits. Closing date: November 15. Appoinlment date: January 15. Send letter, resume, and names of three reierences by November 15 to: Willis E. Bridegam. Librar ian. Amherst College Library. Amherst. MA 01002. EEO/AAIMFH 
CENTRAL REFERENCE LIBRARIAN. The University of Arizona is seeking a prolessional librarian to assist in providing reference ser vice (including evening and weekend rotation), online bibliographic searching and library orientation/instruction. Other activities include humanities subject specialization with emphasis on Slavic or European languages and itterature. Faculty liaison work and collection development. Applicants for this position must be graduates of an ALA-accredited library school, and have either an academic background or academ c library reference experience in Slavic or Western European languages and literature. Candidates should have a broad knowledge of sccial science, humanities, and fine arts refer ence lools. Librarians at the University of Arizona are academic pro fessionals with voting faculty status and have 22 days paid vacation each year, 12 days sick leave, and 10 holidays. Beginning salary is $\$ 17,200$; a higher salary is negotiable based on qualifications. Send resume, including list of three reterees, to: $W$. David Laird, University Librarian, University of Arizona Library Tucson, AZ 85712. Applica tions received prior to November 1,1985 , will be given priority con sideration. The University of Arizona is an equal employment opportunily, affirmative action employer

DIRECTOR, LIBRARY SYSTEMS OFFICE. This is a senior administrative position reporting to the Chair of Systems Management Council (the University Librarian). Under direction of Systems Management Council, the Director facilitates the technical management of the automated library system and assists in planning of automaled systems for all the libraries of the University of Cincinnati. Serves as liaison to vendors. The University is in the process of implementing the $8 \mathrm{~L}$ IS online public catalogue and loading a database of 620,000 records. The Univer sity of Cincinnati is a member of OCLC, Association of Research Libraries, and the Center for Research Libraries. Its libraries serve 35,000 students and 2,500 faculty members. Re. quired qualifications are: MLS from ALA-accredited prograrn or suit able combination of education and experience, data processing. systems design, and management experience in a library setting: demonstrated record of increasing responsibility in a library setting: effective organizational, communication, and human relations skills. Salary is $\$ 25,000$ or above, depending upon qualifications, and the fringe benefits are excellent. Send resume with names of at least three references postmarked by October 31, 1985, to: Sharon Tuffendsam. Personnel Officer. University of Cincinnati Libraries, 640 Central Library, Cincinnati. Ohio 45221-0033. The University of Cincinnati is an equal opportunity, affirmative action employer

DIRECTOR OF LIBRARIES. Cleveland State University is seeking a new Director of Libraries to direct a teaching and research library of over 500,000 volumes, with 23 professional librarians and over 35 support staff. All library collections are housed in a single facility, centrally located on campus. Qualifications: MLS degree from ALAaccredited program. Prefer advanced degree in an academic or professional discipline, with evidence of continued commitment fo scholarly and professional development. Substantial professional experience in academic libraries with evidence of increasing and successful administrative responsibility required. Sound knowledge of current developments in library capacities, including automated systems and services, resource sharing, bibliographic control and management, collection development and management, academic budgeting, fund raising and grantsmanship. Will be responsible for managing internal matters of the library, and capable of representing the University Libraries in the context of the larger University administration. Evidence of strong leadership and management skills with the ability to establish and maintain effective public and professional relationships should be presented Salary is commensurate with experience and qualifications, $\$ 45,000$ minimum, with a renewable anmual contract. Nominations and/or applications with resume and the names, addresses, and telephone numbers of 3 persons who can comment on the candidates' qualifications should be sent by November 15, 1985, to: Barbara Green, Vice Provost, Cleveland State University, 1983 E. 24th Street, Cleveland, $\mathrm{OH} 44115$. Equal opportunity employer $\mathrm{m} / \mathrm{t} / \mathrm{h}$.

DIRECTOR OF THE LIBRARY. Marist College invites applications for the position of Director of the Library. The Director reports to the Assistant Vice President for Academic Aftairs and is responsible for administering a collection of approximately 115,000 print and nonprint items (growing at a rate of 10,000 a year), the budget, and pro. fessional slaff. Marist College Library is a member of the Southeas:ern New York Library Resources Council, a participant in OCLC, and

\section{HEAD, SPECIAL COLLECTIONS DEPARTMENT Florida State University (Search Reopened)}

Qualifications: ALA-accredited master's degree in library science with 9 years professional experience since the MLS in research libraries is required. Candidates for the position should have a strong academic background, preferably the Ph.D. in the humanities or related studies, and have published in their field. Current experience in special collections with supervisory experience of other full-time professionals is preferred. Applicants must have the ability to work effectively with library and faculty colleagues. Appointment shall be at the rank of University Librarian.

Highly desirable: A commitment to publishing bibliographies and scholarly articles about collection strengths in order to publicize and encourage interest in use of the collections by faculty, students, and potential donors. Send resume with samples of publications.

Duties: plans, coordinates, and directs activities of the unit. Supervises 3 librarians, 3 support staff, and student assistants. Manages and develops the department's collections. Participates in development activities in support of the libraries and cultivates close relations with faculty and donors with interests in the collection's strengths and the library. Active in liaison and support of the Friends of the Library. Department includes rare books, manuscripts, archives, Florida materials, and other special collections. Reports to the assistant director for public services.

Salary range is $\$ 21,110-\$ 38,000$, negotiable, based on training and experience. 12-month appointment, optional retirement plan. Eligible for professional development leave (one full semester) with pay after 3 years.

Applications must be received by January 10, 1986, for consideration. Address letter of application, resume, and names of 3 references to: Lois Burdick, Assistant Director for Administrative Services, Strozier Library, Florida State University, Tallahassee, FL 32306-2047. Please cite position no. 53193 . 
ment including developing maintaining and promoting the collec lion: supervising support staff; providirig reference and instructiona service to students, faculty and other users. Qualifications: Required: Master's degree in Library Science from an ALA-accredited pro gram with course work in government documents; undergraduate or graduate concentration in science, technology or bus ness economics: excellent interpersonal and communication skills; strong commitment to public service; knowledge of orinciples of biblio graphic control and collection development; willingness to under lake the research. publication and university-community professional service that is required for tenure and promotion participation in evening and weekend rotation for providing docu ments reference service; willingness to obtain second post-graduate degree in scienoe-technology or business-economics if one is not al ready held. Preterred: Graduale degree in science-technology o business-economics; experlence working with government informa tion; knowledge of oniine reference sources; supervisory experience; ability to promote documenls service and collections to use community. Salary: negotiable, \$16,500-\$24,000. Send letter of ap plication, complete vita, undergraduate and graduate transcripts, names, adcresses and telephone numbers of three reterences to Documents Search Committee, Office of the Dean of Libraries, MSU Libraries, Montana Stale University, Bozeman, MT 59717. Tele phone (406) 994-3119. Deadline for initial screening of applicants is 15 November 1985 although applications will be accepted until the position is filled. MSU is the state's Land Grant University, enrolling approximately 11,000 students. It is situated in Bozeman, a city of approximately 30,000 , located 90 miles north of Yellowstone $\mathrm{Na}$ tional Park. The Documents Department has been a selective federal depository since 1907 and also includes Montana Siate and Cana

\section{ASSISTANT DIRECTOR OF LIBRARIES FOR GRANTS AND DEVELOPMENT Wayne State University Libraries}

This is a Library System-wide administrative position responsible for the establishment of a permanent, ongoing program of development for the Library System. This development program will promote financial growth for the Libraries by increasing the understanding, involvement and support of the needs of the University among alumni, friends, foundations, corporations, government, and the community in general. A major objective of the Libraries development effort will be to establish a strong program of grant applications while coordinating the growth process with appropriate library staff and with the University Development Officer. The principal responsibilities of this Assistant Director will be to (i) support and counsel the Director of Libraries in fundraising, public relations and intramural/extramural communications; (ii) design and implement a planning process re near and long-term goals and objectives; (iii) establish a network of support for the Libraries; (iv) develop and coordinate specific program plans for approval by the Director; and ( $v$ ) participate as a member of the Library System's management team. This position may lead to tenure based on existing standards of evaluation and quality of performance in (i) professional assignments; (ii) creative or scholarly work; and (iii) contributions to the profession. Candidates are urged to review applicable documentation.

Qualifications and desired characteristics: Master's degree from an ALA-accredited library school, with a minimum of five (5) years substantial and successful experiences in an academic library similar in size and complexity to Wayne State University. A second MA or Ph.D. is preferable. Evidence of progressive career achievements and continuing professional and scholarly developments. Good written and oral communication skills. Experience with grant proposal writing and/or fundraising. Understanding the role and function of academic libraries, university presses, and academic programs. Demonstrable competence in handling public relations programs. Successful record in one or more areas related to the basic objectives of this position. Strong leadership, result-oriented managerial traits in combination with good interpersonal skills. High energy level. Reports to Director of Libraries

The University Libraries: Wayne State University Libraries began a dynamic recovery program under the leadership of President Adamany two years ago. A considerable new and higher library funding base has been provided resulting in existing opportunities in collection development, automation, library instruction, and others. Continuation of excellent budgetary support is anticipated for future years.

The Wayne State University Libraries consists of about 2.0 million volumes, 15,000 subscriptions located in five buildings, serving some 30,000 students, of which some $29 \%$ are minorities. The Libraries hold membership in ARL, CRL, and OCLC. The University is classified as a Carnegie I type research institution with a fine reputation in many disciplines. It is one of the great urban universities in an attractive setting, surrounded by museums, theaters and corporation offices, easily accessible by several interstate freeways and from Canada.

Employment Conditions: Liberal fringe benefits, tenure track academic rank, dental and health plan options, TIAA/CREF, tuition breaks to family members. Salary and rank competitive and negotiable based on experience and qualifications. Minimum salary: $\$ 34,000$.

Send application and/or nominations to: James F. Williams, II, Associate Director of Libraries, 134 Purdy Library, Wayne State University, Detroit, MI 48202; (313) 577-4021. Position open immediately and will remain open until filled.

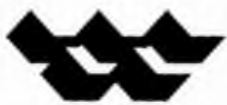


dian federal publications. Montana State University is an equal opporturity, affirmative action employer.

\section{ASSISTANT/SENIOR ASSISTANT LIBRARIAN, SERIALS DE-} PARTMENT. Responsible for production and maintenence of University Libraries' Union List of Serials and for the conversion of General Libraries' manual serials cataloging records to machine-readable form with a staff of 1.6 FTE plus student assistant(s). The ULS contains over 35000 entries for all units of the University Libraries, including Health Sciences and Law. Incumbent will supervise the editing and coding of all additions, deletions, and changes to the LLS; assumes responsibility for development and production of its by-products; and plans, organizes, and coordinates projects to upgrade the quality of bibliographic and holdings data through use of the OCLC and RLIN databases and local files. Also oversees and participates in the conversion of General Libraries' serials cataloging records that are not already in a machıne-readable format, resolves problems and advises staff on matters relating to the identitication of the most authoritative, complete, and correct serial records to be used for updating the bibliographic database. Qualifications: ALA-accredited MLS and post-MLS experience with bibliographic control of serials in an academic/research institution are re quired. A working knowledge of one or more foreign languages and experience with automated union lists are desirable. Salary: $\$ 17,500$ plus depending upon qualifications; faculty status at the rank of Assistant/Senior Assistant Librarian. Send letter of application and re sume including the names of at least three references to. M. E. State Assistant to the Director for Personnel, University Libraries, SUNY Buffalo, 432 Capen Hall, Buffalo, NY 14260. Am EO/AA and Title IX Employer

ASSOCIATE DIRECTOR to coordinate day-to-day operalions of li brary services and to assist in the planning, implementation, devel opment and evaluation of policies, services and personnel. Automa tion has created a generalist environment for our 10 librarians that requires creative administration as we proceed with our integrated catalog/circulation/acquisitions system and reclass to LC. This 12 month position reports to the Director and is the second line administrator. Qualifications include increasingly responsible administrative and supervisory experience in an academic library and an ALA MLS. A public service background is preferred with a willingness to gain an indepth understandıng of all library operations. Excellent benefits include TIAA. Salary approximately $\$ 30,000$. Letter of appilcation by October 30 indicating how your professional goals are compatible with a generalist library environment (include resumes and list 3 references) to Ross Stephen, Director of Library Services Rider College Library, 2083 Lawrenceville Road, Lawrenceville, NJ 08648 . Rider College is an equal opportunity and aftirmative action employer $\mathrm{M} / \mathrm{F} / \mathrm{H}$.

ASSOCIATE UNIVERSITY LIBRARIAN FOR COLLECTIONS AND INFORMATION SERVICES. This is a senior administrative position reporting to the University Librarian. Major responsibilities include planning, budgeting, policy, and procedures of collection development, reference and related information services in the University Libraries system. Shares in the general administration of the Libraries. A division consisting of nine coilege and departmental $\mid i-$ braries and four departments reports to this position. The University of Cincinnati is a member of the Association of Research Libraries the Center for Research Libraries, and OCLC and is in the process of implementing the BLIS systern. Required qualifications are: MLS from an ALA-accredited program, second graduate degree preferred; commitment to planning and to the systems concept; under standing of scholarship and other academic processes; fundamental understanding of technical processing concerns; successful middle management or administrative experience in collection development or reference service in a large academic library. Salary is $\$ 35,000$ or above, depending upon qualifications, and the fringe benefits are excellent. Send resume with names of at least three references postmarked by October 31, 1985, to Sharon Tuffendsam Personnel Officer, University of Cincinnati, 640 Central Library, Cin cinnati, Ohio 45221-0033. The University of Cincinnati is an aftirmative action, equal opportunity employer.

BASQUE STUDIES LIBRARIAN. The University of Nevada Reno Library seeks creative. dedicated librarian with both strong commitment to public service and experience in technical services to be responsible for internationally known Basque Studies collection of about 18,000 volumes: includes collection development, cataloging, reference and other public service. MLS or equivalent 5 th year degree from ALA-accredited program, good knowledge of French,
Spanish or both. Knowledge of Basque language would be a special plus. Appropriate professional experience including calaloging desirable, preferably in an academic or research library. Good supervisory and communications skills. Faculty status requires that librarians meet faculty standards for appointment, promotion and tenure Salary: minimum of $\$ 23.000$ depending upon qualifications and experience. 12-month appointment. TIAAICREF, 24 days vacation Open January 1, 1986. Mountains, desert, lakes, 5 hours by car from San Francisco. Send resume and names and addresses of three references to: Ruth H. Donovan, Associate Director, University of Nevada Reno Library, Reno, NV 89557, by October 31, 1985. An AAVEO employer

BIBLIOGRAPHER FOR HISTORY AND SOCIAL SCIENCE. In COoperation with the Head of the Collection Development Department faculty, and collection development librarians, responsible for collection management and development activities covering Western European and American history, history of science, political science. economics, and business. Assist in the formulation of collection development policies; select material to support curriculum and re search; evaluate collection; manage budget allocations; decide on gifts, replacements, weeding and storage candidates; provide advanced bibliographic instruction and specialized reference assistance on a referral basis. Qualifications: MLS from an ALA-accredited library school; broad history and social science background with minimum of two to three years of experience in collection develop ment or reference in a research library: demonstrated ability in both written and oral communication; reading knowledge of one foreign language required but more desirable. Excellent benefits. Salary dependent upon education and experience. Minimum $\$ 22,000$. Please submit letter of application, resume, and three letters of refer-

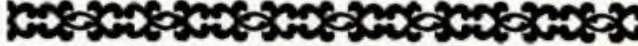 STANFORD UNIVERSITY LIBRARIES}

The Chief, Acquisitions Department is responsible for the management of monographic acquisitions processes, for coordinating these with other technical processing functions and with the Collection Development Program, and is expected to play an important role in general library planning as a senior library officer.

We are seeking candidates who have significant expertise and experience in monographic acquisitions processes; a breadth of experience and understanding of processes in a research library environment; strong management skills; a flexibility of approach toward changing departmental responsibilities and assignments; and a desire to contribute effectively to the overall management of Technical Services. MLS or the equivalent in training and/or experience, effective communication skills, and awareness of automation trends required.

Appointment will bw at the Librarian $(\$ 30,000-\$ 41,500)$ or Senior Librarian $(\$ 34,500-\$ 48,000)$ rank depending upon expeience and qualifications. Apply before November 30, 1985. Refer to vacancy \#276/CRL. Send complete cover letter and resume, with the names of three references to:

\section{Carolyn J. Henderson Library Personnel Officer Stanford University Libraries Stanford, CA 94305}

We are an equal opportunity employer through affirmative action

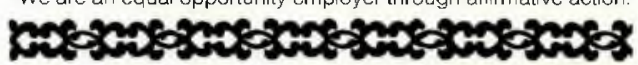


provides computer database searching through DIALOG. Goals o the library include significant expansion of the collection, staft and space, as well as introduclion of advanced library technology. ALA accredited MLS and considerable professional experience at the staff level, culminating in at least 4 years of administrative experience in a college library, preferably in technical services, required Experience coordinating and integrating OCLC functions necessary. The candidale must demonstrate proven ability in personnel administra tion, collection development, fiscal planning, fund raising, and ad vanced library lechnology. The position of library director is an administralive appointment offering a minimum starting salary of $\$ 35,000$ and benefits. Applicants should submit a resume, state ment of professional philosophy, and names and addresses of three references by October 21, 1985, to: Mary Sledge, Personnel Coordi nator, Marist College, Poughkeepsie, NY 12601. An equal opportu nity, affirmative action employer.

GOVEANMENT PUBLICATIONS LIBRARIAN, the University of Nevada Reno Library Head ol extensive Government Publications Department a U.S. Regional Depository, including reference and public service, supervision of 3 library assistants and one libraran collection development, some formal teaching and computer search

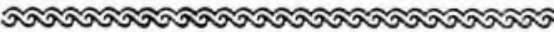 STANFORD UNIVERSITY LIBRARIES}

The Chief, J. Henry Meyer Memorial Library, assesses undergraduate student needs, implements planning of service, administers educational support services and programs, maintains close contact with faculty at Stanford University.

The MeyerChief is responsible for supervision of staff, effective utilization of space, budget preparation and management, coordination of and participation in collection development and reference activities, manages media services, represents undergraduate library services within the library administrative structure and participates in librarywide planning.

Successful involvement with undergraduate education, knowledge of collection development and management and demonstrated capacity to establish effective relationships with and service to faculty and students are required. Familiarity with media services and experience in library public service departments are highly desirable. An MLS with a speciality in academic librarianship or the equivalent in training and experience, plus several years of professional experience are highly desirable; work of a relevant nature outside librarianship (teaching combined with administrative experience in higher education) may be used in fulfillment of this qualification.

Appointment will be at the level of Senior Librarian, $\$ 37,700-\$ 48,000$ annually, depending upon experience. Apply before November 15, 1985. Refer to vacancy $\$ 275 / C R L$. Send complete cover letter and resume, with the names of three references to:

\section{Carolyn J. Henderson Library Personnel Officer Stanford University Libraries Stanford, CA 94305}

services. MLS or equivalent 5 th year degree trom ALA-accredited program, appropriate experience in a government publicalions department or an academic library including familiarity with government publications, computer search experience and experience with microcomputer desirable Strong communications interpersonal and supervisory skills. Faculty status recuires that librarians meet taculty standards for appointment, promotion and tenure. Salary: Minimum of $\$ 24,000$ depending upon qualifications and experence. 12-month appointment, TIAAICREF, 24 days vacation. Open January 1, 1986. Mountains, desert, lakes, 5 hours from San Francisco by car. Send resume and names and addresses of three refer ences to: Ruth H. Donovan, Associate Director, University of $\mathrm{Ne}$ vada Reno Library, Reno, NV 89557, by October 31, 1985. Ar AAIEO employer

HEAD ACQUISITIONS LIBRARIAN. Qualitications. ALA accredited master's degree: five years professional experience in academiciresearch library; supervisory and/or administrative experience in accuisitions ar collection development, substantive knowledge of automated acquisitions systems; tarmiliarity with foreign and domestic book trade and related bibliographic tools, ability lo work effectively with diverse faculty and library statt, broad intellectual background with solid understanding of curriculum and research support in an academic environment, effective written and verbal communications skills. Highly desirable' Working knowledge of one or more European languages; second advanced degree; working experience with IBM PC and related software. Responsibilities: Participates in library policy making, budgel planning, and collection development, maintains financial records; plans and implements automation of acquisitions procedures and coordinates with other ibrary departments. The University of North Carolina at Greensboro is one of three public doctoral granting institutions in the slate with approximately 10,000 students and 650 faculty. The collection consisls of more than $1,500,000$ items including microtexls, has a materials budget of $\$ 1,200,000$ and has been using OCLC since 1975 . Faculty siatus, tenure track, twelve-month appointment, liberal benefils. Position available 5/1/86. Salary: $\$ 30,000$ range depending upon qualifications. Send detailed resume including the names, addresses and phone numbers of at least three references to April Wreath, Chairman Search Commitlee, Jackson Library, UNC. Greensboro, Greensboro, NC 27412-5201. Deadline for applications: November 30, 1985. Affirmative action, equal opportunity em ployer. Applications from minority candidates are strongly encouraged.

HEAD ACOUISITIONS LIBRARIAN. The University of Arizona Library is seeking a librarian to manage its Acquisitions Department and coordinate collection development under the general direction of the Assistant University Librarian for Technical Services. Respon sibilities include the supervision of tour acquisitions librarians who are responsible for selection of monographs in English and European languages, and ten career staft who process and receive or ders and gift materials and who monitor the materials budget using an automated system. Automation planning tor acquisition and serials is underway with plans for implementation in 1986/87. Head Ac quisition Librarian manages the monographic materials budget monitors the library's approval plans and blanket orders, works closely with other librarians and faculty in matters related to acquisitions and collection development, and will chair the Collection Development Committee. Head represents the department on library. wide administrative and planning committees. The University of Arizona Library serves a community of 36,000 students and faculty. its collection is over 2.8 million volumes. The $1985 / 86$ acquisitions budget exceeds $\$ 3.7$ million. The library adds more than $90,000 \mathrm{vol}-$ umes to the collection annually. Applicants must have a master's degree in library science from an ALA-accredited school; substantial and increasingly responsible management experience in collection development, acquisitions, or a closely related area; demonstrated leadership, supervisory ano planning skills and the ability to commu nicate effectively with stall at all levels and with faculty. Applicants should have experience in managing materials budgets and work ing with approval plans; and be farriliar with the domestic and foreign book trade and with developments in automation for acquisitions. Working knowledge of a foreign language is desirable Minimum salary is $\$ 31,000$; higher salary is negoliable, depending upon qualifications and experience. Librarians at the U of A have academic professionai status, are voting members of the faculty, and may take up to 15 days professiona leave per year. They have 22 days paid vacation, 12 days sick leave, and 10 holidays. A standard package of fringe benefits is available. A letter of application, re sume, and names of 3 referees should be sent to: $W$. David Laird, 
University Librarian, University of Arizona Library, Tucson, AZ 85721. Applications received prior to November 30, 1985, will be given first consideration. Position available immediately. The University of Arizona Library is an equal employment opportunity, affirmative action employer.

HEAD, CATALOG DEPARTMENT, University of Cincinnati. Re sponsible for the management of the centratized cataloging ser vices; the transition from card to online catalog: and for the manage ment of the online catalog of the University Libraries System. In process of implementation of the BLIS online catalog and loading database of 620,000 records. U.C. is a member of ARL, CRL, and OCLC. Position reports to the Associate University Librarian. Re quired qualifications are: MLS from ALA-accredited program; demonstrated leadership, management and human relations skills and successful supervisory experience; five years progressively responsible experience in technical services in a large library, some public service experience highly desirable; demonstrated understanding of contemporary cataloging rules and procedures; experience with a cataloging subsystem on a major bibliographic utility; reading knowledge of one language in addition to English; ability to commu nicate clearly, both orally and in writing. Minimum salary: $\$ 30,000$ rank and salary dependent upon qualifications and experience Send resumes with cover letter and names of three references post marked by October 31, 1985 to: Sharon Tuffendsam, Personnel Offi cer, 640 Central Library, University of Cincinnatı, Cincinnatı, Ohio 45221-0033. The University of Cincinnati is an equal opportunity, af firmative action employer.
HEAD CATALOGER. Georgetown University is looking for a librar ian to head its Cataloging Department. The Department is responsi ble for original cataloging, OCLC processing, Geac System data base maintenance, bindery and physical preparations, maintenance of the card catalogs. Applicants must have an MLS de gree from an ALA-accredited school: relevant management experi ence in cataloging; supervisory and planning skills; the ability io work effectively with staff at all levels; two modern foreign languages; experience with OCLC. Experience with retrospective conversion creating databases, and automated cataloging issues is desirable Minimum salary: $\$ 28,000$. Excellent fringe benefits. Position open November 1985. Send resume by October 31st to: James DeLan cey, Georgetown University Library, P.O. Box 37445, Washington DC 20013. Georgetown University is an affirmative action, equal op portunity employer

HEAD, CATALOGING DEPARTMENT, LAW LIBRARY. Adminis ter all phases of the cataloging deparlment which includes facilitating transition from OCLC to RLIN, participating in planning for online cat alog. and cataloging and classifying library materials. Assist the Di rector in planning for automation, coordinating cataloging services priorities with teaching and program needs of law school, and pre paring budget and reports. Work closely with acquisitions/serials librarian and other departments to provide the most effective access to the collection. Qualitications: ALA-accredited MLS, demonstrated managerial ability, minimum two years' experience in academic li. brary cataloging services, and working knowledge of AACR2 and either RLIN or OCLC are required. Graduate degree in an area rele

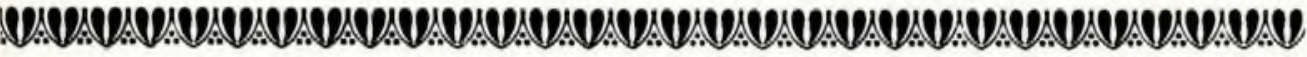 TWO POSITIONS
}

\section{Texas A\&M University}

1) Reference librarian, Microtext Department (entry level). Provides comprehensive reference assistance from the Microtext collection of 2.2 million microforms, one of the largest in the nation. Prepares bibliographies and guides to the literature. Assists with bibliographic instruction and computerized reference services. Assists with Microtext collection development and with training and supervision of four support staff. Assumes responsibility for operation of the Department in the absence of the Head, Microtext Department, including six weeks each summer. Qualifications: ALA-accredited MLS. Preprofessional experience with microtext materials and experience with online systems of bibliographic data retrieval desirable. Salary: $\$ 16,500$ for 10.5 months; $\$ 17,500$ with second master's. Position available January 1,1986 .

2) Preservation librarian and original cataloger, maps. Preservation duties (50\%): Implements and revises policies and procedures for the handling of materials in unusable condition and the protection of materials during disasters. Coordinates activities relating to preservation of library materials, determining the best methods and procedures, including use of outside restoration facilities. Makes decisions related to retention, replacement, and deselection of damaged materials. Supervises one full-time support employee. Assists with collection evaluations as time permits. Map cataloging duties (50\%): Catalogs and classifies sheet maps in all languages and subjects. Duties include creation of original cataloging and review of subject headings, classification, and descriptive cataloging on OCLC cooperative cataloging. Participates in meetings of Original Catalogers and in development of divisional policies, procedures, and plans. Qualifications: ALA-accredited MLS. Minimum of one year professional (post-MLS) experience. Requires experience in either preservation and conservation or in original cataloging with AACR2 and LC classification and subject headings. Salary: Open-ended depending on qualifications; minimum $\$ 17,500$ for 10.5 months. Position available immediately.

Closing date: To ensure full consideration, applications for either position should be received by October 25. Benefits: Competitive benefits package. No state income tax. Faculty rank. For complete description of duties, qualifications, and benefits, and to apply, contact:

\author{
Susan S. Lytle \\ Head, Personnel Operations \\ Evans Library \\ Texas A\&M University \\ College Station, TX 77843 \\ (409) 845-8111
}

AA/EEO employer.

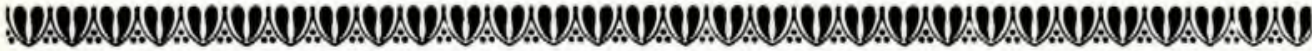


vant to law librarianship, experience in a law library, and experience with an automated library system such as Geac are highly desirable. Faculty status at the rank of Assistan: Senior Assistant Librarian. Salary: Appointment as Assistant Librarian at $\$ 19,000$ plus depending upon qualifications; appointment as Senior Assistan! Librarian at $\$ 21,000$ plus depending upon qualificalions. Send letter of applica. tion and resume including the names of at least three references 10 M E. Stale, Assistant to the Direclor for Personnel, University LI braries, SUNY/Buffalo, 432 Capen Hall, Buffaio, NY 14260. An EO/AA and Title IX Employer.

HEAD HUMANITIES DIVISION, with faculty rank. Position reo pened. Responsible for the Humanilies Public Services Division of the Library airecting the work of three professional librarians, three nonpiolessionals, and tour student assistants. Supervise collection development for materials in all fiteratures and languages, religion, the fine arts, architecture. generai periodicals, library and intorma tion science, journalism, sporls and recreation. Sit on the library di rector's council and serve on council commitlees concerned with overall library operalion. Masters degree from an ALA-accredited library school: a bachelors or second masters in a discipline in the hu manities; at least five years experience in an academic library public services position, preferably in the humanities Initial appoinıment wilh laculty rank of instructor with advancement to Assislant Protes sor at the end of first year if merited. Good fringe benefits. Salary. $\$ 22.500$ minimum. For full consideration application should be re ceived by November 1, 1985. Submit letter of application with re sume including names of three references to Roscoe Rouse, Universily Librarian, Oklahoma State University, Stillwater, OK 74078 AAIEO Employer.
HEAD OF CATALOGING, Librarian II. Under the Assistant Direclor for Technical Services, responsible for the management of the Cataloging Department for the UMKC Library system. Supervise department personnel ( 3 professionals, 11 support staff, misc. studenls) to catalog materials for the main library. 4 prolessional school libraries and 2 branches Plan and review quarterly objectives and monthly production statistics. Update department procedures and participale in the development of policies and procedures affecling the Technical Services division. Flay significant role in transition Io universily-wide online union catalog using OCLC tapes and WLN software. Requirements include MLS from an ALA-accredited school; successful superviscry experience; management skills; serials ano monographic cataloging experience wilh AACR2, LC classificalion and subject headings; experience with automated biblio graphic utility' 5 years recent academic library experience. Salary: $\$ 26,500-\$ 28,400$ Standard benefits. Application deadine: Octo ber 31 . 1985. Position available: Immediately. Send letter of applica tion, resume and the names of three references to: Helen $\mathrm{H}$. Spalding. Asscciate Direclor of Libraries, University of Missouri-Kansas Cily Libraries, 5100 Rockhill Road, Kansas Cily, MO 64110; (816) 276-1531. An equal opportunily institution.

\section{HEAD OF SPECIAL COLLECTIONS/ARCHIVES DEPARTMENT} (Search extended). Montana State University seeks a creative and energelic person to head the Special Collections/Archives Department which houses books, manuscripts, architectural drawings, maps. photographs and artifacts relating to the history of Montana, the Pacific Northwesl, and Native Americans. The Head of Special Colleclions/Archives is responsible for the acquisition, organization, description, security, and preservation of the malerials in Special

\section{HEAD TECHNICAL SERVICES}

\section{Albert R. Mann Library Cornell University}

Cornell, the land grant university of New York State, is known worldwide for its teaching and research programs of the College of Agriculture and Life Sciences and the College of Human Ecology. Mann Library, which supports these programs with 550,000 volumes and 9,500 current serials, is the largest academic agricultural and life sciences ibrary in the United States, and its collection is second only to the $\mathrm{Na}$ tional Agricultural Library. The Cornell University Library system is a member of the Research Libraries Group.

Responsibilities: Administers Technical Services Division, composed of the Acquisitions and Continuing Education Unit and employing five professional and ten support personnel. Formulates library policy relating to the acquisition and bibliographic control of all library materials (monographs, serials, sottware, etc.). Coordinates acquisitions and bibliographic control operations and programs with the Collection Development Division and other CUL system units. Provides leadership in the organization of division programs related to the development and implementation of an integrated library system, retrospective conversion projects, and automated support activities. Performs original or copy cataloging of materials in various formats.

Requirements: MLS from an ALA-accredited institution. Experience in a large academic/research library, with a minimum of three years administrative responsibilities in technical services, including supervision of professional librarians. Demonstrated knowledge and understanding of acquisitions, cataloging, and serials processes, including knowledge of the U.S. and foreign book trade, AACR2, LC classification and subject headings, and RLIN (or other large bibliographic utility). Subject expertise or demonstrated interest in agriculture, the life sciences or human ecology, and some foreign language ability is desirable. Demonstrated organizational ability, strong interpersonal skills, imagination and creativity. Excellent oral and written communication skills. Familiarity with computer applications and library processes.

Applications requested by November 15, however, applications will be accepted until the position is filled. Salary up to $\$ 29,000$; higher salary negotiable depending on qualifications. Send resume listing 3 references to:

\section{Carolyn Pyhtila \\ 201 Olin Library \\ Cornell University \\ Ithaca, NY 14853}


Collections and the University Archives (a 1/4 time records management operation); provides reference service in these collections; prepares grant proposals for special project funding; is active in the acquisition of additions to these collecitons; trains and supervises clerical and student staff; and is expected to participate in library and university committees. The Head of Special Collections/Archives reports to the Assistant Dean for Public Services. Qualifications: MLS from an ALA accredited institution required. Graduate degree in American history, history of science, Native American studies or other related area of stuoy desired and eventually required for promotion. Three years of experience in special collections work in an academic library (including processing, cataloging, and indexing and servicing special collections) required. Training or experience in archival organization and records management desired. Experience in computer applications in libraries desired. Must demonstrate ability to work effectively with colleagues, administrators, patrons and donors in an academic environment. Must demonstrate ability to communicate effectively, both orally and in writing. Appointment and salary Position available immediately. Tenure Irack, FY position at the Assistant Professor level, $\$ 22,000$ minimum. Candidate must be prepared to meet university requirements for promotion and tenure. Montana State University is an affirmative action, equal opportunity employer and encourages applications from female, minority and disabled persons. Application procedures: Send letter of application, resume and the names of three references to Special Collections Search Commitlee, c/o Dean of Libraries, Roland R. Renne Library, Montana State University, Bozeman, MT 59717-0022 Applications must be received or postmarked no later than October 31. 1985

HEAD OF TECHNICAL. SERVICES. University of Arkansas at Little Rock. Administers overal operations of collection development, cataloging, and physical processing. Responsible for coordination of biblographic files throughout the library. Some night and weekend work should be expected. Qualifications include understanding of automated library systems, thorough knowledge of cataloging policies and procedures; demonstrated abilities in management, abil ity and willingness to communicate effectively and work well with all levels of employees. ALA/MLS required. Five years of relevant postMLS experience preferred. Minimum salary $\$ 25,000$ with five years experience Immediate opening. Position is faculty-rank, tenuretrack, 12-month, full-time with good fringe benefits. Send resume and names of three references (with titles, addresses, and phone numbers) who have observed human relationships and professional abilities to: Library Search Committee, c/o Kathy Essary, Chair, University of Arkansas at Little Rock, 33rd and University, Little Rock. AR 72204. The University of Arkansas at Little Rock is an affirmative action, equal opportunity employer and actively seeks the employment of minorities and women.

HEAD, RICHARD C. RUDOLPH ORIENTAL LIBRARY. Under the general direction of the Head of the Reference Department, responsibilities include direction of the operations of the library, long-range planning, and coordination with other East Asian libraries and collec tions throughout the country. Specific responsibilities include policies, programs; public and technical services; collection management; personnel management; funding, expenditure contral; space utilization; and the promotion of good relations with faculty, students, and the public. Candidates must have demonstrated competence in librarianship and administration in a complex organizationat environ ment. Competence in reading, writing, and speaking either Chinese or Japanese. Ability to communicate effectively in written and spoken English. Familiarity with research trends and university teaching requirements for East Asian studies. Understanding of academic library services or comparable library services. Graduate degree in an aspect of East Asian studies and familiarity with library automation developments and their apolication to Chinese, Japanese and Korean materials desirable. Salary range is $\$ 25,692-\$ 43,464$ Prefer application by November 1, 1985 with complete slatement of qualifi cations, resume and names of three references to: Rita A Scherrei, Director of Administrative Systems and Personnel Services, Univer sity Research Library, UCLA, 405 Hilgard Avenue, Los Angeles, CA 90024 For more information call (213) 825-1201. UCLA is an Equal Opportunity, Affirmative Action Employer. Librarians are repre sented by an exclusive bargaining agent, the American Federation of Teachers

LIBRARIAN. Haverford College, an independent non-sectarian liberal arts college founded in 1833 by the Religious Society of Friends (Quakers), invites applications and nominations for the position of Li- brarian of the College. The position is available July 1, 1986. Re sponsibilities: The Librarian reports to the Provost and is responsible for the total mission of the library, including services, budgets, per sonnel, and acquisitions. The library has a staff of 9 professionals and 12 full-time non-professionals, plus other part-time help. The library currently holds 450,000 volumes and 250,000 manuscripts. It co-operates closely with the library of Bryn Mawr College, and is studying the possibilities of automation and further linkages in the near future. Qualificalions: ALA-accredited master's degree; secono master's or Ph.D. desirable. Minimum of five years administrative ex perience in comparable library. Salary Range: We expect to hire in the full-professor salary range, currently $\$ 36,500-\$ 64,500$. Applications and nominations should be sent to: Harry Payne, Provost Haverford College, Havertord, PA 19041-1392. Deadline, November 1, 1985. AA/EOE

MANUSCRIPTS LIBRARIAN. Under the direction of the Head of Manuscripts, Archives and Special Collections, supervises the operations of the manuscripts programs within the unit. Responsibilities include analyzing and maintaining the collection; selecting, training and supervising support staff appraising, processing, arranging and cataloging collections applying computer-based techniques to the control of and access to collections; reference; preparing exhibits; writing grant proposals; development and public contacts; physical maintenance and preservation of the collections. Collection develop-

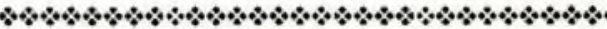 STANFORD UNIVERSITY LIBRARIES}

The Head Librarian and Bibliographer of the Music Library provides a full range of quality services for the faculty and students of the Stanford University Department of Music.

The Head Librarian and Bibliographer plans, develops, maintains and improves the services and collections of the Music Library in Stanford's new Braun Music Center in support of the research and training programs of the Music Department. The Head Librarian maintains close contact with faculty to ascertain research and instructional programs, develops and manages music collections to meet academic program needs, manages the facility and staff of the Music Library and the Archive of Recorded Sound and provides instruction in music bibliography

Knowledge of and experience in academic libraries, the fields and literature of music and musicology, and the distribution of music materials in North America are required. Supervisory experience required. Reading knowledge of German, Latin or French highly desirable. An MLS or the equivalent in theory and practice, and a degree in musicology or music are highly desirable.

Appointment will be at the rank of Librarian, $\$ 30,000-\$ 41,500$ annually, depending upon experience. Apply before November 15, 1985. Refer to vacancy \#272/CRL. Send complete cover letter and resume, with the names of three references to

\section{Carolyn J. Henderson Library Personnel Officer Stanford University Libraries Stanford, CA 94305}

We are an equal opportunity affirmalive action employer 
ment responsibilities are shared with the head of the unit. Tenuretrack position. Required: ALA-accredited MLS manuscripts/archival experience; communication skills. Preferred: supervisory experience tamiliarity with computer applications to manuscripts/archival processing: knowledge of Pacific Northwest history; master's degree in social sciences or humanities; knowledge of historical research methods visual afchives (historical photographs) experience. Rank: Librarian II. Salary commensurate with qualifications and experience, minımum $\$ 17,500$. TIAAICREF. Broad insurance program, 22 days vacation and 12 days sick leave per year. Send letter of application, resume, and names and addresses of three references to: Donna L. McCool, Assistant Director for Administralive Services, Washington State University Libraries, Pullman. WA 99164.5610. Application review begins November 15, 1985. Washington State University is an equal opportunity, affirmative action emoloyer .

\section{STANFORD UNIVERSITY LIBRARIES}

The Chief, Science Department and Curator of Science and Technology Collections, plans, develops, maintains, and improves an excellent program of research support services for the academic schools, departments and programs in the sciences and technology at Stanford University. The Science Chief is head librarian of the Engineering Library and oversees the libraries of Earth Sciences, Biology, Marine Biology, MathematicsIComputer Science, Physics and Chemistry.

Assesses the library and informational needs of the science and technology community, defines goals, coordinates collection development efforts, participates in library-wide planning and evaluates program effectiveness. Maintains close contact with faculty, coordinates departmental services with graduate and undergraduate academic programs, manages budget and facilities, and supervises staff

Demonstrated familiarity with and understanding of the science and technology programs in a research university is required. Knowledge of collection development and management principles for science and technology collections is required. MLS or the equivalent in theory and practice, substantial professional experience, and an advanced degree in one of the sciences or technology disciplines are highly desirable. Work in a related fieid (teaching and administrative experience in higher education) may be used in partial fulfillment of this qualification.

Appointment will be at the rank of Librarian $(\$ 30,000-\$ 41,500)$ or Senior Librarian (\$34,500-\$48,000) depending upon experience. Apply before November 29,1985 . Refer to vacancy \#271/CRL. Send complete cover letter and resume, with the names of three references to:

\section{Carolyn J. Henderson \\ Library Personnel Officer \\ Stanford University Libraries Stanford, CA 94305}

REFERENCE AND BIBLIOGRAPHIC INSTRUCTION LIBRAR-

IAN. Provides reference and research services in the social sciences and humanities; plans, coordinates and implements an integrated bibliographic instruction program for Case Western Reserve University Libraries; has collection management responsibilities in as signed subject areas. Required: Accredited MLS, two years protes sional experience in an academic library with at least a one-year concentration in library instruction/orientation activilies, traıning and experience in computer database searching. Preferred: Subject background in the social sciences or humanities; second master's degree, knowledge of OCLC or other bibliographic utility, educa tional media experience, a working knowledge of one or more for eign languages, familiarity with microcomputer-based applications. Rank and salary. Hiring range $\$ 18,220-\$ 23,085$. Send resume and names of three current references to: Karen K. Griffith, Personnel Li brarian, Case Western Reserve University Libraries, 11161 East Boulevard, Cleveland, Ohio 44106, by November 15, 1985. An ecual opportunity, affirmative aclion employer

REFERENCE LIBRAAIAN, Cudahy Library. Lovola University of Chicago. Experienced database searching librarian with a strong background in the sciences. Will coordinate online searching for a department of 5 librarians and provide collection development liai son with science departments. Shares departmental responsibility for service at the reference desk and for library instruction program Reports to the Head of Reterence. Qualificalions: Accredited MLS demonstrated knowledge and experience in database searching, at least 3 years academic reference experience; science subject background, excellent communication skills and a strong commitment to public service. Salary: Mirimum \$21,000 depending on qualifica tions. Deadline: November 1, 1985. Qualified applicants should send a letter, resume, and names of 3 references to Mary J. Cronin. Director of Libraries, Loyola University of Chicago, $6525 \mathrm{~N}$. Sheridan Road. Chicago, IL 60626.

REFERENCE LIBRARIAN. Full-time, tenure-track position. In cludes night and week-end assignments. Some bibliographic in struction and book selection. Required: MLS from ALA-accredited library school, plus second masters. Experience in academic library preferred. 12 month position. Rank of Assistant Professor with a salary of $\$ 24,120$. Starting date, January, 1986. Librarians hold faculty rank and are evalualed in areas of primary duties, research and service. Deadline for applications November I, 1985. Send letter of ap plication and references 10: Eugene Moushey. Reference, University Library. Western Illinois Unversity, Macomb, Illinois 61455. WIU is an equal opportunity/affirmative action employer

REFERENCE LIBRARIAN. Provides general reference service in the Main Library. Emphasis is with students and faculty in engineering and applied sciences. Activities include extersive online database searching, bibliographic instruction, faculty iiaison, and collec tion development. Parlicipation in the planning currently underway for a separate science and technology library to be in operation within two years. Presently reports to the Head. Reterence/Documents Department. Main Library: will report to Head, Science and Technology Library following the opening of that facility in 1987. ALA-accredited MLS. Preferred qualifications include an academic degree in a scientific or technological discipline (e.g, engineering. mathematics, computer science) and a minimum of two years post MLS experience in an academic or special library. Proficiency in online database searching preferred. Facility with Western languages, especially German, desirable. Library faculty must meet university requirements for promotion and tenure. Tenure-lrack position. 24 days annual leave. Tuition remission. Group health insurance. TIAAICREF or state retirement plan with non-refundable contributions paid by the university. No state income tax. Rank and salary dependent upon education and experience Instructor: $\$ 16,500-\$ 18,500$; Assistant Professor: $\$ 18,500-\$ 20,500$. Send letter of application, current resume, and the names, addresses, and telephone numbers of 3 recent references by November 15, 1985 to: Jill Keally, Personnel Librarian. The Universily of Tennessee Library, Knoxville. TN 37996-1000. UTK is an EEO, Affirmative Action, Title IX, Section 504 Employer.

REFERENCE LIBRARIAN, University of Georgia, Main Library. Two entry-level positions to be filled between January 1 and July 1 1986 (minimum salary $\$ 16,500$ ). The Reference Department in cludes 12 librarians and 3 support staff reporting to the Head of Reference. Duties: General reference service in social sciences and hu manities with some weekend and evening work; preparation of bibliographies and gundes: participation in bibliographic instruction 
programs and library orientation tours; reference collection building in assigned subject areas; online searching. Qualifications: ALA. accredited MLS; advanced reference courses in the social sciences or humanities or relevant experience; Working knowledge of basic relerence sources; ability to communicate effectively and to work well with colleagues and library users; interest in library orientation bibliographic instruction, and computerized database searching undergraduate degree in the social sciences or humanities prefer red; demonstrated interest in academic librarianship preferred working knowledge of at least one foreign language desired. Applcation procedures: Send letter of application by November 1, 1985 including resume and names of three references to: Linda Green Staff Services Librarian, University of Georgia Libraries, Athens, Georgia 30602 . This position will be filled only if suitable applicants are found. An equal opportunity, affirmative action institution.

REFERENCE/RESOURCE COORDINATOR, SCIENCE (Search reopened). General reference dulies approximately 20 hours per week. Remairing time spent in working with teaching faculty in coor dination of selection, collection evaluation, and resource develop ment in the physical sciences. Online searching and previous aca demic reference experience preferred. NSU is a regional instilution of 7,500 nestled in the Green Country mountain and lake area of Northeast Oklahoma. Tahlequah is the capital of the Cherokee $\mathrm{Na}$ tion, one hour's drive from Tulsa. Library/Learning Resource budge of $\$ 1,000,000+$, with a faculty of 15 and staff of 19 . ALA-accredited MLS required. Instructor rank, $\$ 20,000$, 9-10 month, additiona summer contract possible. Applicalion, resume, transcripts and three letters of reference due October 21, 1985, to Office of Personnel Services, Northeastern Slate University, Tahlequah, OK 74464 An equal opportunity, affirmative action employer

SCIENCE LIBRARY, University of Georgia. Two entry-level positions to be filled between January and June 1986. Applicants will be considered for both Science Bibliographer and Science Reference Librarian with final decision on appointment title and emphasis on either collection development or reference duties dependent upon successful candidate(s) background and interests. (Salary minimum $\$ 16,500$ ). Recent graduates will have the opportunity to participale in a special staff development orogram funded by the Council on I brary Resources. Duties: Science Bibliographers and Reference Li brarians are responsible for developing the Science Library collec tion in assigned areas and for providing reference, instructional and referral services. Collection development duties involve selection and evaluation of materials and liaison to faculty in academic departments. Reference duties involve assisting students, faculty and staff in making effective use of library resources, including government documents and science databases. The Science Library serves the biomedical, agricultural, and physical sciences. The $76,000 \mathrm{sq}$. $\mathrm{ft}$. facility has 430,000 volumes and 5,500 current journal subscriptions with a staff of 28. Qualifications: ALA-accredited MLS; working knowledge of basic reference resources; knowledge of database searching; ability to communicate effectively; ability to establish and maintain effective workıng relationships; ability to evaluate re. sources; familiarity with science literature desired; strong inlerest in academic librarianship desired; ability to work with a foreign language desired. Application procedure: Send lelter of application by November 1, 1985, including resume and names of three refer ences, to: Bonnie Jackson Clemens, Assistant Director for Adminis. trative Services, University of Georgia Libraries, Athens, GA 30602 This position will be filled only if suitable applicants are tound. An equal opportunity, affirmative action institution

SCIENCE-ENGINEERING REFERENCE LIBRARIAN. The Univer sity of Arizona is seeking a professional librarian to provide reference, online searching, and bibliographic instruction services in its Science-Engineering Library. Additional responsibilities include collection development, faculty liaison work, and the possibility of coor dinating one or more service activities within the Science Engineering Library. A separate branch of the University Library, the Science-Engineering Library occupies a 5 -story building in the center of campus and houses a collection of 380,000 vo lumes and ove one million microforms covering all fields of the pure and applied sciences, except clinical medicine, and has a staff ot 7.5 professiona and 6.5 career staff. Required: ALA-accredited degree; either an academic background in the sciences, or public service experience in an academic science library or special library; good communication and interpersonal skills. Desired: Educational background or library experience in chemistry or other physical science; online searching: and bibliographic instruction experience. Also, working knowledge of Spanish, German, or Russian. Position available January 1, 1986 Minimum salary $\$ 17,200$; higher salary is negotiable, depending on cualifications and experience. Librarians at the University of Arizona have 12 month appointments, are voling members of the faculty. have 22 days vacation and 12 days sick leave. Usual fringe benefits available. Aoplications received by November 15,1985 , will be given priority consideration. Send resume, including list of three referees, to: W. David Laird, Universify Librarian, University of Arizona Library, Tucson, AZ85712. The University of Arizona is an equal employment opportunity, affirmative action employer

SCIENCE REFERENCE LIBRARIAN. Duties include general and specialized reference services, bibliographic instruction, database searching, and responsibility for developing and promoting services to the science departments. Qualifications: MLS (accredited). Science background Second masters preferred. Strong interpersonal skills. Position availabie January 2, 1986. Starting salary $\$ 19,500$ Send applications and have three letters of reference forwarded to Bernice K. Lacks, Head of Readers Services, Vassar College Library, Poughkeepsie, NY 12601, by November 1, 1985. AA/EO employer.

SERIALS CATALOGER. Responsibility for calaloging English and foreign language serials using AACR 2 rules as well as formating and MARC tagging copy for input into the WLN database. Required: ALA-accredited MLS. Desirable: Experience in serial cataloging USing $L C$ classification, both pre-AACR and AACR 1 rules, preterably in an academic library; ability to work with foreign languages com. monly encountered in academic libraries; experience in general serials processing, e.g. check-in binding, acquisitions, etc. Rank: Librarian 2. Salary: (minimal professional salary is $\$ 17,500$ ). TIAA/CREF broad insurance program, 22 days annual ieave, 12 days sick leave per year. Send letter of application, resume, and names of three reterences to: Donna L. McCool, Assistant Director for Administrative Services, Libraries, Washington State University, Pullman, WA 99164-5610. Review of applications begins November 15, 1985 Washington State Universily is an equal opportunity. affirmative action employer

ACQUISITIONS BRANCH HEAD, National Agricultural Library. Responsible for the administration of the Acquisitions Branch (15 FTE) including selection, purchasing, fiscal control, and related activities. Reports to the Chief, Technical Services Division. Starting salary: $\$ 37,599$. Qualifications: knowledge of acquisitions theory and practice; knowledge of automated technical services systems; skill and management of a large staff; knowledge of the organization, operation, and practices of large libraries; excellent communications skills. Candidates must request a copy of the vacancy announcement which (a) more fully describes the duties, qualifications requirements and quality ranking factors for this position, and (b) gives specific instructions for applying, from: Ivy Hungerford, USDA, Agricultural Research Service, Personne1 Operations Branch, Headquarters-H01, Room 107, 
Building 003, BARC-W, Beltsville, MD 20705; (301) 344-2701. A personal qualifications statement, SF171, must be received no later than November 1 , 1985. U.S. citizenship required. Resumes will not be accepted. Candidates with specific questions about the position may contact: Sarah Thomas at NAL, (301) 344-3834. Affirmative action, equal opportunity employer.

ASSISTANT/ASSOCIATE LIBRARIAN FOR COLLECTION DEVELOPMENT, Yale University Library. Responsibilities: Has primary responsibility for planning and carrying out the effective development of the Yale Library collection and for developing collection objectives, policies and procedures in the Yale Library system. Advises the University Librarian and Deputy University Librarian on system-wide collection management and development issues and on related budgetary matters. Directs the work of the Bibliography Department, including leadership and supervision of a staff of four bibliographers, one supervisor and seven support staff. Serves as Yale Library's principal resource person and spokesperson on collection development. Represents Yale Library in regional and national collection development forums. Selects research resources in one or more academic fields in the social sciences or humanities. Qualifications: Collection development experience, preferably at least five years, in a major research library, including primary responsibility for selection of research resources in one or more fields in the humanities or social sciences. A thorough understanding of bibliographic sources and processes. Capacity to manage effectively a major library department, including the ability to organize, prepare and implement long-range plans. Evidence of a thorough understanding of collection development issues in an academic setting. Advanced graduate work in a field of the humanities or social sciences, Master's degree from an ALA-accredited 1ibrary school, and reading knowledge of two foreign languages preferred. To be assured of consideration, please submit a letter of application, resume, and the names of three references by November 15, 1985, to: Maureen Sullivan, Head, Library Personnel, Box 1603A Yale Station, New Haven, CT 06520. Yale is an equal opportunity, affirmative action employer.

ASSISTANT HEAD, PRESERVATION DEPARTMENT. Under general direction of Head of Preservation Department, position assists in managing and coordinating work of the department and participates in all phases of departmental activities. Specific duties include gathering and analyzing information for use in departmental planning; reviewing procedures in light of changing technologies, and recommending revisions as appropriate; administering of both short-term and ongoing projects that implement preservation policy; and supervising department staff in the course of carrying out responsibilities. Also serves as technical resource for other department and library units, participates in development and implementation of training programs for library staff and users, and acts as department head in absence of head. Required: MLS from ALA-accredited library school; training in library materials preservation; experience in physical treatment of library materials; and knowledge of current preservation issues and concerns. Successful candidate must be able to communicate effectively orally and in writing. Must be able to work well independently and with others, and to meet responsibilities and requirements of tenure-track position. Preferred: post-MLS experience in research library; experience in training and supervising staff; experience with information preservation. Salary dependent on qualifications and experience, minimum $\$ 16,000$. Fringe benefits: vacation of 22 working days; Blue Cross/Blue Shield, major medical; group life insurance; TIAA/CREF annuity plan. To apply send letter of application and names of four references to: Anne Rimmer, Personnel. Librarian, Indiana University Libraries, Bloomington, IN 47405; (815) 335-3403. Available immediately. Closing date for applications: no earlier than November 1, 1985. EEO/AAE. 
CATALOGER OF RARE BOOKS AND SPECIAL COLLECTIONS, Lilly Library, Indiana University-Bloomington. Under the general supervision of the Head of Technical Services, Book Department, Lilly Library, catalogs printed rare books and special collections materlals in specialized areas, e.g., incunabula, major rarities, and general books mostly prior to 1800; advises and consults with other catalogers on bibliographical terminology, collations, bindings, etc.; shares in planning, supervision, and general operations of the Book Department; performs other general library duties as required. Required: Master's degree in library science from an ALA-accredited school; at least three years of cataloging experience with rare books and special collections materials; broad general knowledge of the humanities; knowledge of LC classification, LC subject headings, AACR2, and the appropriate MARC formats; ability to relate effectively to other library staff members and to the University community; ability to meet the responsibilities of faculty status. Preferred: Reading competence in Renaissance Latin and German; working knowledge of Spanish and French; competence in additional languages; training and experience in rare book bibliography and in the techniques and terminology of analytical bibliography; book trade experience; working knowledge of OCLC; supervisory training and experience. Salary dependent on qualifications and experience (salary floors are observed: Assistant Librarian, $\$ 16,480$; Associate Librarian, $\$ 20,650)$. Fringe benefits: vacation of 22 working days; Blue Cross/Blue Shield, major medical; group life insurance. Available immediately. Closing date for applications: no earlier than November 15, 1985. Apply to: Anne Rimmer, Personnel Librarian, Indiana University Libraries, Bloomington, IN 47405; (815) 335-3403. EE0/AAE.

COORDINATOR OF TECHNICAL SERVICES AND PRINCIPAL CATALOGER, Columbus College. Coordinate technical services functions (cataloging, acquisitions, periodicals, physical processing). As princlpal cataloger, train, supervise and coordinate all cataloging operations and personnel. Assist the Director in planning for implementation of computer-based technology. Assist with reference and bibliographic instruction. Requirements: MLS from an ALA accredited institution. Minimum of 3 years' related experience, including supervisory experience. Experience with OCLC, or some other bibliographic utility, knowledge of AACR2, LCSH. Knowledge and experience in planning and implementing automated systems in libraries highly desirable. Good communication and interpersonal skills. Academic rank depending on qualifications. Excellent fringe benefits. Salary commensurate with experience, minimum $\$ 22,000$. Available: immediately. Application deadilne: october 21, 1985. Columbus College, a member of the University System of Georgla, is a comprehensive institution located in the second largest city in the state. The curricula range from certificate to cooperative doctoral degree offerings and from programs in the health and business professions to those in the fine arts. The Library serves approximately 4,000 students. To apply, send letter, a complete resume, and names of three references to: Merryl1 S. Penson, Director, Simon Schwob Memorial Library, Columbus College, Columbus, Georgia 319932399. Columbus College is an affirmative action, equal opportunity institution.

EAST ASIAN CATALOGER. Under direction of Cataloging Department, position is responsible for original cataloging of monographs in Chinese and Japanese using Anglo-American Cataloging Rules, 2d edition, and Library of Congress classification and subject headings. Also responsible for training and supervision of student assistants and support staff. Required: MLS from ALA-accredited library school; working knowledge of Chinese and Japanese with specialization in one; previous cataloging experience; ability to communicate effectively orally and in writing in English; practical and theoretical knowledge of Anglo-American Cataloging Rules, 2d edition, Library of Congress 
subject headings and classification, current developments in cataloging; ability to deal with materials on variety of subjects, solve problems, work with great attention to detail; ability to work well independently and with wide variety of people, and meet responsibilities and requirements of tenuretrack appointment. Preferred: working knowledge of Korean; practical and theoretical knowledge of MARC format; experience with OCLC and/or other bibliographic utility; acadenic concentration in East Asian studies; previous supervisory experience. Salary dependent on qualifications and experience, minimum $\$ 16,000$. Fringe benefits: vacation of 22 working days; Blue Cross/Blue Shield, major medical; group life insurance; TIAA/CREF annuity plan. To apply send letter of application and names of four references to: Anne Rimmer, Personnel Librarian, Indiana University Libraries, Bloomington, IN 47405; (815) 335-3403. Available immediately. Closing date for applications: no earlier than November 1, 1985. EEO/AAE.

HEAD, CATALOGING UNIT, Assistant Professor. Requirements: ALA-accredited MLS, 2d masters. Substantial supervisory and cataloging experience in an academic library. Knowledge OCLC, AACR2, LCSH, MARC formats. Familiarity with current technology for integrated systems. Salary $\$ 21,650+$. Generous benefits. Appointment February 1, 1986. Deadline November 15, 1985. Equal opportunity, affirmative action employer. Resume, 3 references to: Ben DiRusso, York College, CUNY, Jamaica, NY 11451.

HEAD OF CATALOGING SERVICES, Ball State University. Major administrative post with responsibility for cataloging procedures/standards for print and nonprint collections. Supervisory responsibility for 5 professional librarians and 12 classified staff of the cataloging services unit. Unit includes monographic and serials cataloging, plus OCLC activities. Head will participate in implementing automated system (retrospective conversion project nearing completion; RFPs received for automated circulation, public-access catalog, acquisitions, and serials control; vendor selection during fall). Qualifications: accredited MLS, broad knowledge of and experience in cataloging, OCLC, or other bibliographic utility, LC classification, LC subject headings, and AACR2 are required. Innovative leadership, initiative, analytical ability, and good written and verbal communication skills are necessary. Supervisory experience desirable. Conditions: salary negotiable from $\$ 25,000,12-$ month contract. Fringes include partial tuition remission for dependents, 24 vacation days, 8 holidays, TlAA, and life and health insurance package. Faculty rank and status possible with appropriate background. Transcripts (copies acceptable) must be received, before interviews can be scheduled. Credentials must be recefved by Monday, November 18 , and the position will remain open until filled. Send resume and names and addresses of 3 professional references to: Nyal Williams, Chair, Department of Library Service, Ball State University, Muncie, IN 47306. Ball State University practices equal opportunity in education and employment.

HEAD, REFERENCE DEPARTMENT, University of California, Santa Barbara. Responsible for overall planning and administration of all resources in department of 14 librarians and 19 support staff. Manages reference collection of 30,000 volumes serving humanities and social sciences. Works closely with nine other department heads of library. Requires MLS degree, understanding of and comitment to the educational and public service function of academic research library; ability to provide leadership and motivation through a period of change; understanding of online database services; bibliographic instruction and collection of management and development of reference sources in the humanities and social sciences. Salary range for Associate Librarian/Librarian is $\$ 27,156-\$ 50,604$. Apply by November 15, 1985, with letter of application, resume and names of three references to: Margaret 
Deacon, AUL-Personnel, UCSB Library, Santa Barbara, CA 93106. UCSB is an $\mathrm{AA} / \mathrm{EOE}$.

LIBRARY DIRECTOR, Whitman College. Whitman College invites applications for Library Director to begin July 1, 1986. Whitman is a traditional residential, selective liberal arts college enrolling 1,100 students, with an endowment of $\$ 66,000,000$. The Penrose Library has a collection of 481,173 volumes and a staff of five professionals and seven support personnel who report to the Director. The annual acquisitions budget exceeds $\$ 350,000$ and the library is a member of Western Library Network and a selective depository for federal and state documents. Responsibilities: The Director reports to the Dean of the Faculty and has an overall responsibility for planning and management of the library. He/she will direct the continuing development of the collection and the extension of automated services to the catalogue and other appropriate functional areas. Qualifications: The candidate must have an understanding of and commitment to undergraduate liberal education and at least five years of varied experience at academic libraries; MSLS or equivalent required, subject area $\mathrm{Ph} . \mathrm{D}$. desirable; essential are abilities to communicate with faculty and staff, to work with the Faculty Library Committee, to plan budgets, and to manage technological change while retaining a love of books. Salary at least $\$ 31,000$ with competitive benefits. Submit letter of inquiry, curriculum vitae, and a list of references to Edward E. Foster, Dean of the Faculty, Whitman College, Walla Walla, WA 99362. Applications will be reviewed beginning November 1 . AA/EOE.

LIFE SCIENCES REFERENCE LIBRARIAN/BIBLIOGRAPHER. Responsible for the Library's collection development in biology and other assigned disciplines. Provides service at the Reference Desk, including some weekend and evening hours. Participates in an active program of library instruction and computerized database searching in the disciplines of selection responsibility. Requires a Master's degree from an ALA-accredited library school. Significant coursework in pertinent science disciplines or science reference experience preferred. $\$ 16,500$ minimum salary. Excellent benefits including choice of retirement programs. The University of HoustonUniversity Park Libraries have 1.4 million volumes; a materials budget of $\$ 2.4$ million, and a staff of 58 professionals and 200 support staff. To ensure consideration, applications must be received by November 30, 1985. Send letter of application, names of 3 references, and resume to: Dana Rooks, Assistant Director for Administration, University of Houston Libraries, 4800 Calhoun, Houston, TX 77004. Equal opportunity employer.

ORION USER SERVICES HEAD, UCLA. Responsible for coordinating all userrelated functions of the UCLA Library's online information system, ORION, including soliciting staff input, specification writing, documentation, and training. (ORION includes acquisitions, serials processing, catalog, bindery, fund accounting, authority control, and public access modules with circulation module under development.) Broad management responsibility for departmental operations, including personnel (12 FTE), budget, and planning. Qualifications: Excellent managerial, planning, leadership, communication, and interpersonal skills; experience working in a complex library network environment; ability to analyze and synthesize information quickly. Knowledge of MARC record formats, technical processing/circulation functions, online library computer systems, and telecommunications are highly desirable. Salary range: $\$ 27,156-\$ 45,936$, based on qualifications and years of experience. Send letter, resume, names of 3 references to Rita A. Scherrei, Director, Administrative Systems and Personnel Services, University Research Library, UCLA, Los Angeles, CA 90024. Candidates applying by December 1, 1985, will be given first consideration. Full job description is available on request. 
UCLA is an equal opportunity, affirmative action employer. Librarians are represented by an exclusive bargaining agent, the American Federation of Teachers. This position is exempt from the bargaining unit.

ORION USER SERVICES LIBRARIAN, UCLA. (ORION online system includes acquisitions, serials processing, catalog, bindery, fund accounting, authority control, and public access modules with circulation module under development.) Shares responsibility with other OUS Librarians for systems analysis functions; works with library staff and committees; writes system specifications for programmers to enhance existing or develop new modules; tests system releases; organizes and teaches formal and informal training classes for UCLA Library and non-UCLA library staff using ORION; writes and revises user documentation; responds to software questions from library staff. Serves as member of ORION Design and Implementation Group. Incumbent may be assigned coordination responsibilities for a specific ORION module based on expertise and interest, taking into account the skills of existing staff. Qualifications: general knowledge of MARC formats; experience in online technical processing or circulation operations in a complex library or network environment; written and verbal communication skills; interpersonal skills; ability to analyze, synthesize and interpret technical information. Desirable qualifications include demonstrated ability in systems analysis, experience in microcomputer applications, and training experience in use of automated systems. Salary range: $\$ 27,156-\$ 41,712$ based on qualifications and years of experience. Two positions. Send letter, resume, names of 3 references to Rita A. Scherrei, Director, Administrative Systems and Personnel Services, University Research Library, UCLA, Los Angeles, CA 90024. Candidates applying by December 1, 1985, will be given first consideration. Full job description is available on request. UCLA is an equal opportunity, affirmative action employer. Librarians are represented by an exclusive bargaining agent, the American Federation of Teachers.

PUBLIC SERVICES LIBRARIAN, Fort Lewis College Library, Durango, Colorado, is seeking a Public Services Librarian with strong reference and communication ski11s. We need a generalist who will be able to perform a wide variety of of duties, including staffing the reference desk, teaching bibliographic instruction sessions, participating in collection development, online searching with DIALOG, and anything else that may come up in a college library. Requirements: Master's degree from ALA-accredited library school and 2 years of public service experience. Desirable: Degree in business or science, online searching experience, bibligraphic instruction experience. Setting: Fort Lewis is a 4-year state-supported college of 3,800 undergraduate students located in the La Plata Mountains of Southwest Colorado. Durango is a tourist town of 13,000 year-round population. Skiing and other recreational activities abound. The library holds 160,000 volumes, is a member of BCR and OCLC, and is rapidly developing other automated systems. Conditions: Position available January 1, 1986. Salary between $\$ 18,000$ and $\$ 22,000$, depending on experience, appropriate faculty rank and status, 12-month contract, liberal fringe benefits. Some evening and weekend work required. Apply to: Dan Lester, Director of the Library, Fort Lewis College, Durango, Co 81301, by November 10, 1985, with letter, resume, and names of three professional references who will not be contacted until the final stages of screening. Fort Lewis College is an AA/EEO employer and actively encourages minority applications.

REFERENCE LIBRARIAN, Instructor. Requirements: ALA/MLS, 2d masters desirable. Responsible for general reference assistance. Academic library and reference experience essential. Good communication skills. Knowledge of OCLC and collection development. Salary $\$ 19,858+$. Generous benefits. Appointment 
February 1, 1986. Deadline November 15, 1985. Equal opportunity, affirmative action employer. Resume, 3 references to: Ben DiRusso, York College, CUNY, Jamaica, NY 11451 .

REFERENCE LIBRARIAN/DATABASE SEARCH SERVICES COORDINATOR. Hunt Library of the Carnegie-Mellon University Libraries has an immediate vacancy for an innovative and creative librarian who will coordinate the Database Searching Services for the library. The Coordinator will be responsible for developing and marketing search services on campus. Will share general reference responsibilities including desk duty, bibllographic instruction, database searching and committee activities. Collection development and liaison responsibilities will be in the social sclences, urban and public affairs, statistics, and engineering and public policy. Required: An ALA-accredited MLS. Extensive experience searching databases. Good oral and written communication skills. Knowledge of collection development. Strong service orientation with a commitment to creative approaches to information services. Preferred: Experience supervising or coordinating a major 1ibrary program. Degree or significant coursework in the social sciences. Knowledge of at least one modern foreign language. Reference experience in an academic 1ibrary. Salary: Depends upon experience and qualifications, $\$ 16,500$ minimum. Applicants should submit resume and names of three references to: Administrative Services, Hunt Library, Carnegie-Mellon University, Pittsburgh, PA 15213. Preference given to applications received by october 15, 1985. CMU is an.equal opportunity affirmative action employer.

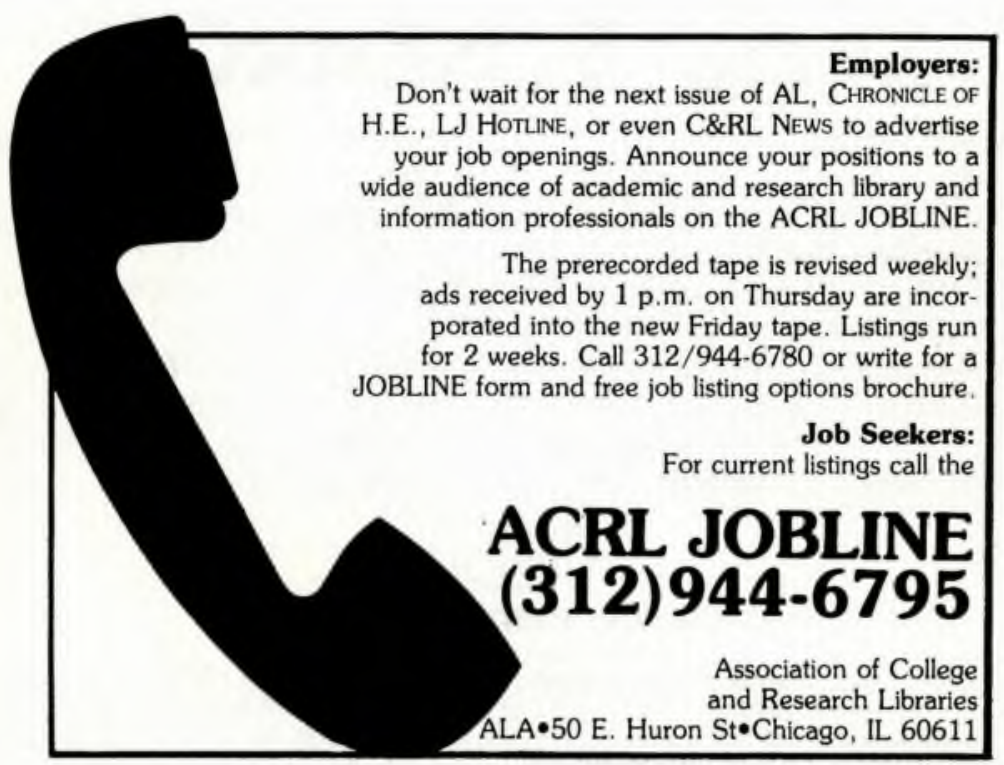




\section{When people rely on you}

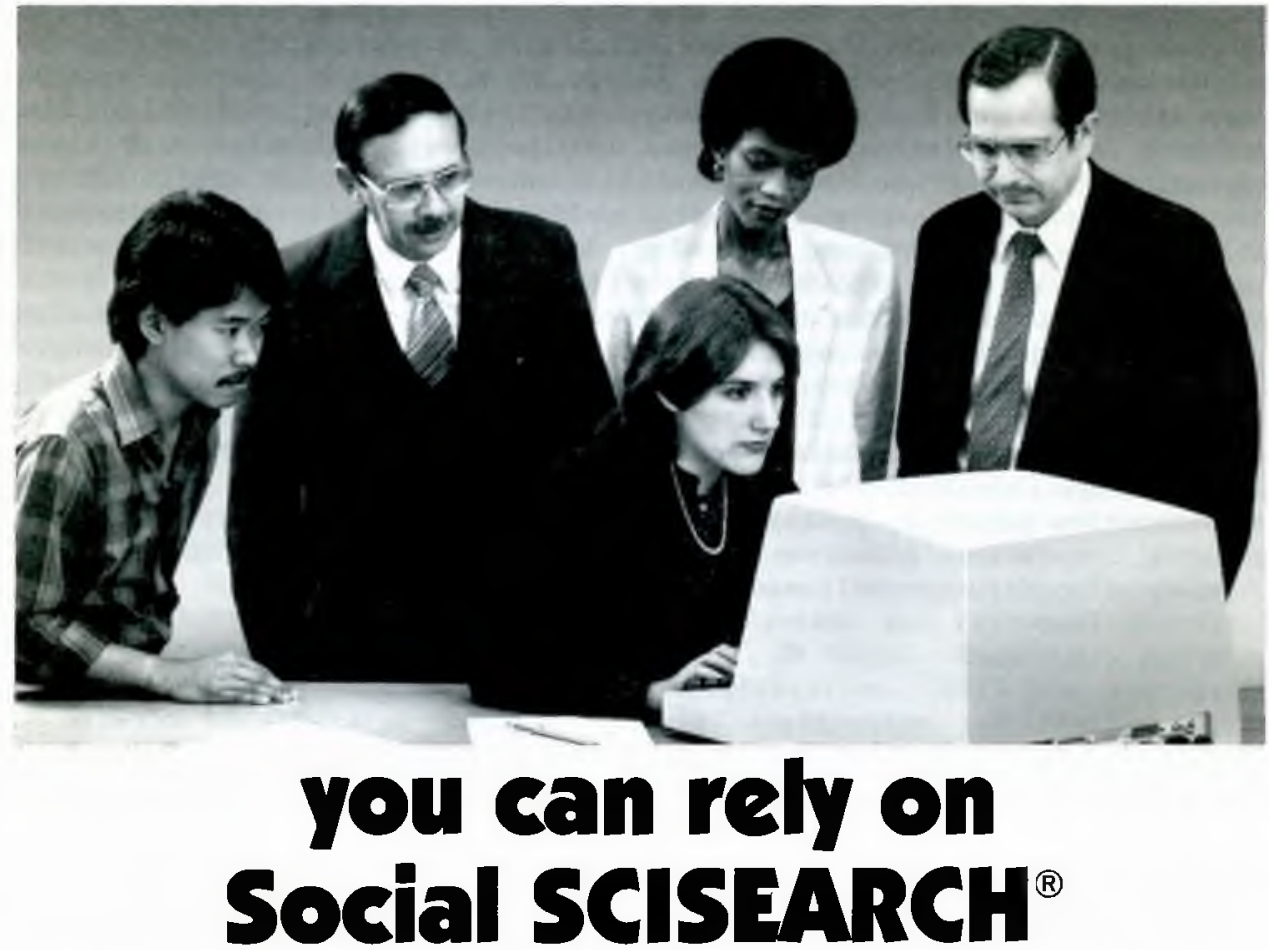

When you're asked to perform a literature search in the social sciences, you can depend on Social SCISEARCH for coverage and for currency.

Social SCISEARCH provides full coverage of over 1400 journals from the worldwide social sciences literature, plus items relevant to the social sciences from an additional 3200 journals in the natural, physical, and biomedical sciences. And rapid journal processing and frequent updates ensure the currency that Social SCISEARCH users need.

Social SCISEARCH is available on DIALOG, BRS, and DIMDI. To find out how you can start searching Social SCISEARCH, call us toll-free: 800-523-1850, extension 1371. In Pennsylvania, call collect: $215-386-0100$, extension 1371.

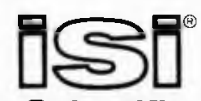

\section{Institute for Scientific Information ${ }^{\oplus}$}

Customer Services Department

3501 Market Street, Philadelphia, Pennsylvania 19104 U.S.A.

Telephone: (215) 386-0100, ext. 1371, Cable: SCINFO, Telex: $84-5305$

European Office: 132 High Street, Uxbridge, Middlesex UB8 1DP, United Kingdom (९) 1984 Is। Telephone: 44-895-70016, Telex: 933693 UKISI 


\section{ACRL Publications in Librarianship -}

\section{Your special perspective on the profession.}

\section{Series titles currently available:}

39. Libraries for Teaching, Libraries for Research: Essays for a Century, Richard D. Johnson, ed.

"... a must for all library school students interested in academic librarianship.' ARBA 78

$\$ 15.00 \mathrm{cl}$. 259p. 0247-2 (use order code 3196-0) 1977

40. Book Selling and Book Buying: Aspects of the Nineteenth-Century British and North American Book Trade, Richard G. Landon, ed. "... these essays, five of them on bookselling and two... on book collecting, fit together admirably." Book Collector's Market \$15.00cl. 118p. 3224-X 1979

41. Women View Librarianship: Nine Perspectives, Kathryn Renfro Lundy, ed.

"It is satisfying to read their considered responses to questions ranging from ideas about administration and personal career choices to developing library school curricula and advice to beginning professionals." College \& Research Libraries $\$ 8.00$ pbk. 99p. 3251-7 1980

42. The Spirit of Inquiry: The Graduate Library School at Chicago, 1921-51, by John V. Richardson, Jr. “... a significant book in library education and an example of painstaking historical research." $A R B A 84$ \$35.00cl. 238p. 3273-8 1982

43. The Landscape of Literatures: Use of Subject Collections in a University Library, by Paul Metz.

"Metz provides... an important use study...by attempting to identify the subject literature of interest to faculty and students in various academic disciplines." $R O$,

$\$ 30.00$ pbk. 143p. 3286-X 1983

44. The Carnegie Corporation and the Development of American College Libraries, 1928-41, by Neil A. Radford.

Provides a useful historical perspective on collection analysis and external funding by studying the impact of Carnegie grants for collection development.

$\$ 29.95$ pbk. 257p. 3295-9 1984

\section{Order from}

American Library Association

Publishing Services

50 East Huron St.

Chicago, IL 60611

(ISBN prefix 0-8389) 


\section{Acronyms, Initialisms \& Abbreviations Dictionary \\ Selected as one of the most distinguished reference works of the past 25 years! $-R Q$ Fall 1985}

1986-87 Edition - Just Published!

... A Guide to Acronyms, Initialisms, Abbreviations, Contractions, Alphabetic Symbols, and Similar Condensed Appellations.

10th Edition. Edited by Julie E. Towell and Helen E. Sheppard. (Vol. 1 of Acronyms, Initialisms \& Abbreviations Dictionary.) 2,400 pages in 3 parts. 340,000 entries. $\$ 170.00 /$ set. Available at Gale's 5\% Standing Order Discount.

\section{Alphabetitis epidemic}

The 340,000 entries in this new edition attest to the increasing role acronyms have in modern communication. Daily news headlines are peppered with initialisms like OPEC, SALT, FTC, SEC, and MIRV. Acronyms, Initialisms \& Abbreviations Dictionary fills the need for a comprehensive resource to translate these terms.

Identify words and phrases behind the acronym

For the past twenty-five years AIAD has been serving the needs of businesspeople, government officials, students, and researchers. Anyone who requires a high degree of accuracy in reading, writing, and research can depend on AIAD to eliminate the guesswork in translating thousands of terms.

\section{New features}

The new 10th edition includes new fields such as: Biblical and Judaic acronyms ... Stock exchange symbols for Toronto... and acronyms for research centers. In addition, overall Canadian coverage has been expanded, and there is increased coverage in every field: Communications . . . Data Processing . . Education . . . Entertainment ... Finance... Medicine... Military Affairs ... Science and Technology ... Social Welfare... Transportation ... and more.

Order tollfree! 800-223-GALE.
When you know the term and need the acronym

Reverse Acronyms, Initialisms \& Abbreviations Dictionary

10th Edition. Edited by Julie E. Towell and Helen E. Sheppard. (Vol. 3 of Acronyms, Initialisms \& Abbreviations Dictionary.) 2,400 pages in 3 parts. $\$ 195.00 /$ set. Available at Gale's 5\% Standing Order Discount.

Thousands of complex terms from every area of knowledge are acronymized. This "backwards" volume - arranged alphabetically by the complete word or term. with the acronym as the definitionenables researchers to locate the accepted short forms of organization names and technical terms in hundreds of fields.

\section{Keep current between editions}

\section{New Acronyms, Initialisms \&} Abbreviations

Supplements to Volumes 1 and 3 of AIAD. Edited by Julie E. Towell and Helen E. Sheppard. 2 softcover supplements. \$150.00/set. Available at Gale's 5\% Standing Order Discount.

Due to the rapid proliferation of acronyms, Gale offers an inter-edition supplement service. For convenience, New Acronyms gives both the acronym and the reverse form in two sections, By Meaning and By Acronym.

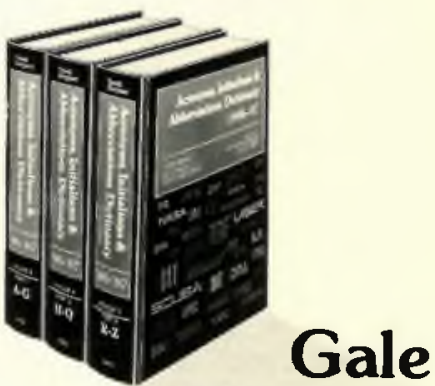

Research Company

Book Tower - Detroit, Ml 48226

All Gale books are available on 60-day approval. Deduct $5 \%$ if you send check with order. Add 10\% outside the U.S. and Canada. 